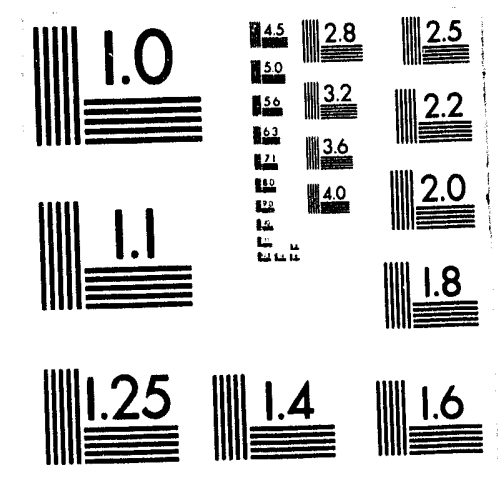



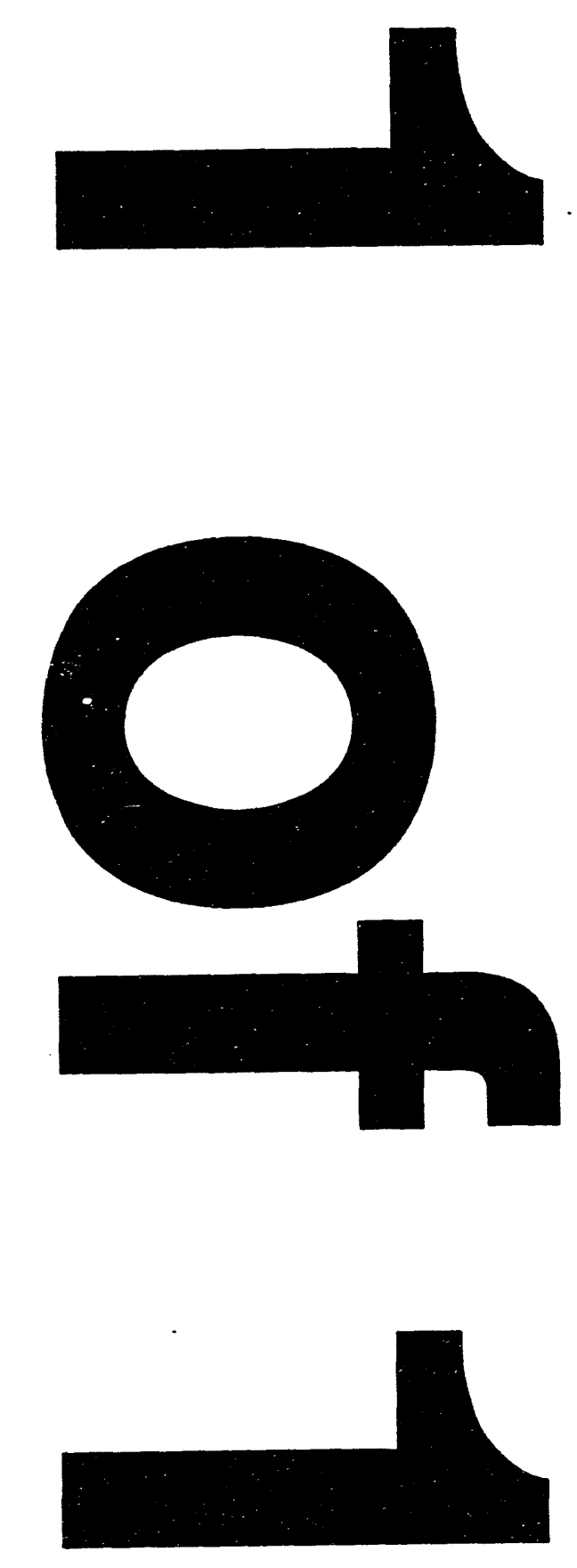
LA-UR- $92-1144$

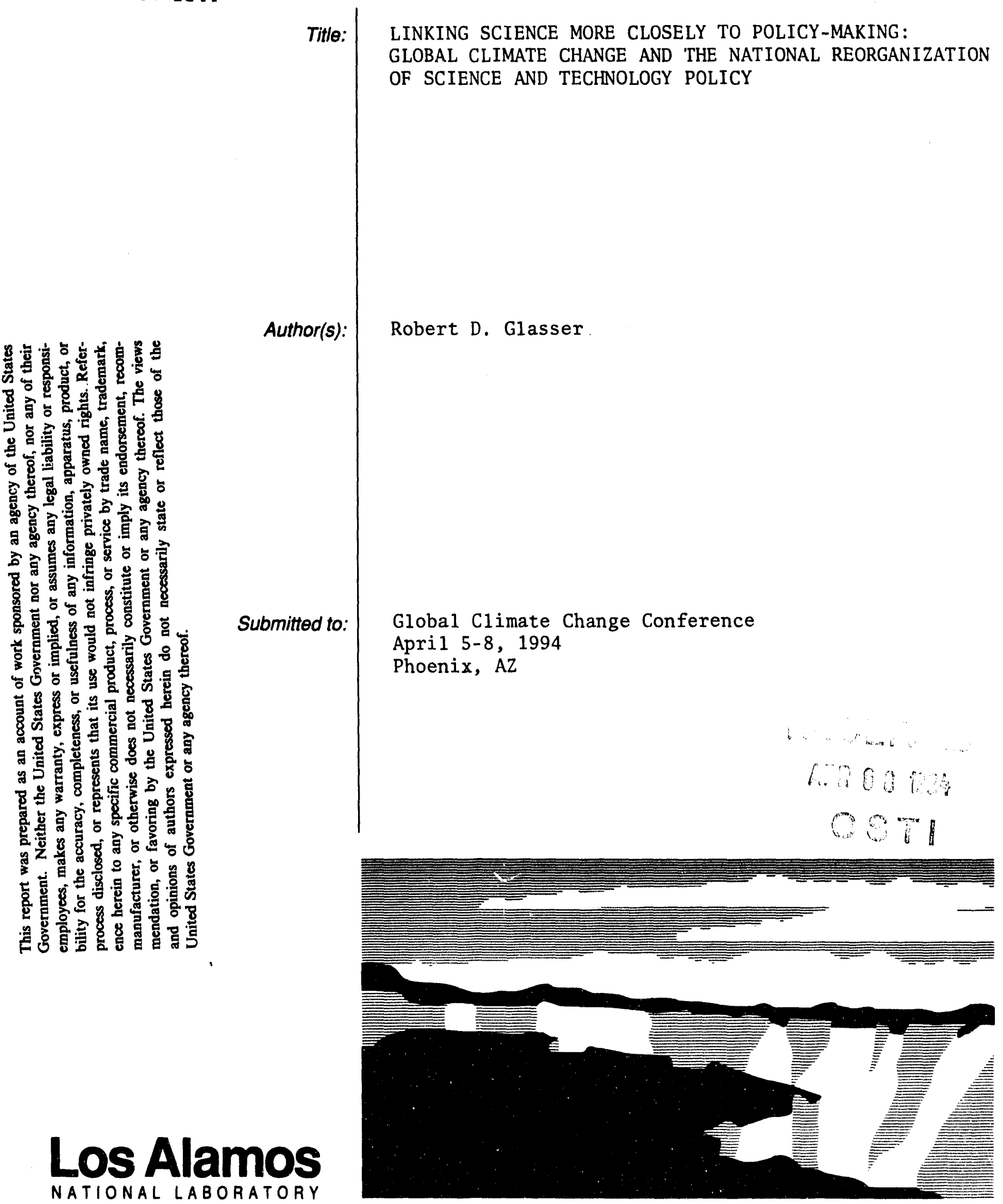

Los Alamos National Laboratory, an affirnative action/equal opportunity employer, is operated by the University of California for the U.S. Department of Energy under contract W-7405-ENG-36. By acceptance of this article, the publisher recognizes that the U.S. Government retains a nonexclusive, royalty-free license to publish or reproduce the published form of this contribution, or to allow others to do so, for U.S. Government purposes. The Los Alamos National Laboratory requests that the publisher identify this anticle as work performed under the auspices of the U.S. Department of Energy. 0.2 


\title{
Linking Science More Closely to Policy-Making: Global Climate Change and the National Keorganization of Science and Technology Policy
}

\author{
Robert D. Glasser \\ Center for National Security Studies \\ Los Alamos National Laboratory \\ P.O. Box 1663, MS C306 \\ Los Alamos, NM 87545
}

\begin{abstract}
This paper examines the national trends behind recent efforts to link science and technology more closely to policy-making. It describes the politics surrounding the establishment of the National Science and Technology Council and its Committee on Environment and Natural Resources (of which the global change program is a part). It discusses the evolution of the "assessments" function within the climate change program in general, and within the Department of Energy, in particular, and how the Clinton Administration's approach to climate change "assessments" differs from that of its predecessor. The paper concludes with a critique both of the national reorganization of science and technology policy and of the assessments component of the climate change program.
\end{abstract}

\section{INTRODUCTION}

In September of 1991, Congressman George Brown, Jr., the Chairman of the House Committee on Science, Space, and Technology, wrote to John Gibbons the Director of the Office of Technology Assessment (OTA) to request that the OTA explore the connections between the climate change science program managed by the Committee on Earth and Environmental Sciences (CEES) and the key climate change policy issues the Congress might have to confront in the coming decades. In particular, Brown asked Gibbons:

Can you identify those natural systems (such as wetlands and forests) and built systems (such as dams and ports) likely to be most sensitive to climate changes? For which of these must we make decisions about human interventions (i.e. to maintain systems' functions or services) relatively soon? Similarly, can we delay decisions for a decade or two, expect few adverse consequences for such a delay, and wait for the results of ongoing research programs?...In particular, how does the CEES ...decide overall research strategies, and is this process likely to effectively answer the questions posed above?

It was not surprising that Congressman Brown was concerned (as were many of his colleagues') that inadequate attention was being paid to assessing the societal implications of climate change. Just a few months earlier, Congress had been exposed to a scathing critique of another large science initiative, the National Acid Precipitation Assessment Program (NAPAP), primarily on the grounds that NAPAP failed to incorporate "assessments" adequately. ${ }^{2}$

Over the past two years, the U.S. global change research program has begun stepping-up its effort to link climate change science more closely to policy-making. In part, this is due to the emergence of the Clinton Administration, which is eager to take action on climate change and anxious to assure that its policy recommendations are informed by science as much as possible. At the same time, this increased emphasis on assessments has been bolstered by larger national trends relating to disillusionment with "big" science, the economic recession, and renewed attention to a pressing social agenda.

Disillusionment with big science was demonstrated most recently with the cancellation of the Superconducting Super Collider (SSC), an \$11 billion dollar project involving thousands of scientists and engineers. The SSC's fate can be explained by its escalating costs coupled with enduring doubts that the basic research it would conduct would yield any discoveries of material benefit to society. It can 
also be traced back to a string of events--the Chernobyl disaster, the Shuttle Challenger accident, the plight of the Hubble Telescope, and the recent loss of NASA's multi-billion dollar Mars probe, to name a few--that are negatively shaping the public's perceptions of science and technology.

At the same time, the nation finds itself emerging only slowly from an enduring economic recession and confronting pressing domestic problems relating to crime, healthcare, and drug abuse, among many others. The end of the Cold War has contributed to the expectation that the time is right to address these previously neglected domestic priorities. Under these circumstances, it did not take long for policymakers to begin wondering how effectively science was responding to national needs and, eventually, to begin mandated that it should. Senator Barbara Mikulski, for example, the Maryland Democrat who heads the Senate subcommittee that overseas the budgets of the NSF, NASA, and EPA, recently startled the scientific community, by warning that if the NSF does not pursue "activities where science leads to technology, products, and jobs," her appropriations subcommittee would cut its budget by up to twothirds. ${ }^{3}$ According to the Congressional committee report issued by Mikulski and approved by the full committee:

The committee believes the National Science Foundation is at a crossroads in its

future...In short, the foundation can be at the heart of helping to shape the

Administration's science and technology policy in pursuit of specific national goals or it can diminish into becoming nothing more than a national endowment for science...

In the case of the climate change program, these national trends are re-enforcing the efforts to expand human impacts and assessments research. Senator Max Baucus, for example, recently called on President Clinton to shift his global climate change budget priorities away from scientific research to fund mitigation measures because as he saw it "the key scientific questions about global warming will not be solved for some time."

\section{THE NATIONAL SCIENCE AND TECHNOLOGY COUNCIL (NSTC) AND ITS COMMITTEE ON ENVIRONMENT AND NATURAL RESOURCES (CENR)}

In September 1993, the Clinton Administration released the recommendations of a National Performance Review (NPR), which codified the national trend toward increasing scientific accountability and the Clinton Administration's desire for policy action to address environmental problems like climate change. The NPR recommended that the Federal Coordinating Council for Science and Engineering and Technology (FCCSET), of which the Global Change Research Program (GCRP) was a part, be re-structured to "strengthen its role in science policy."

The FCCSET was the primary means for coordinating multi-agency research and development initiatives in areas ranging from high performance computing to bioscience. In theory, the FCCSET planned, budgeted, and coordinated government-wide, cross-cutting R\&D initiatives to ensure the most efficient use of Federal R\&D funds. In practice, as the NPR pointed out, the FCCSET "lacks the teeth to set priorities...nor can it tell agencies how to spend funds." Most importantly, the FCCSET did not address what the President's Science Advisor John Gibbons and Office of Management of the Budget (OMB) Director Leon' Panetta considered among the most serious flaws in the science and technology process: the fact that the existing system was organized inadequately to provide necessary information about the relevance to society of national investments in science. ${ }^{6}$

The NPR proposed superseding the FCCSET (and the National Space and Critical Materials Councils) with a National Science and Technology Council (NSTC) which would manage the R\&D budget more tightly by virtue of its closer connections to the OMB. On November 23, 1993, President Clinton formerly accepted the NPR's recommendation by issuing an executive order establishing the NSTC as a cabinet-level organization, chaired by the President and involving the participation of the Vice-President, various agency heads, the President's Science and Technology Advisor, the Director of the NSF, and the Director of OMB, among others. ${ }^{7}$ Nine R\&D Coordinating Committees were established within the NSTC:

Health, Safety and Food R\&D

Fundamental Science and Engineering Research 


\section{National Science \& Technology Council}

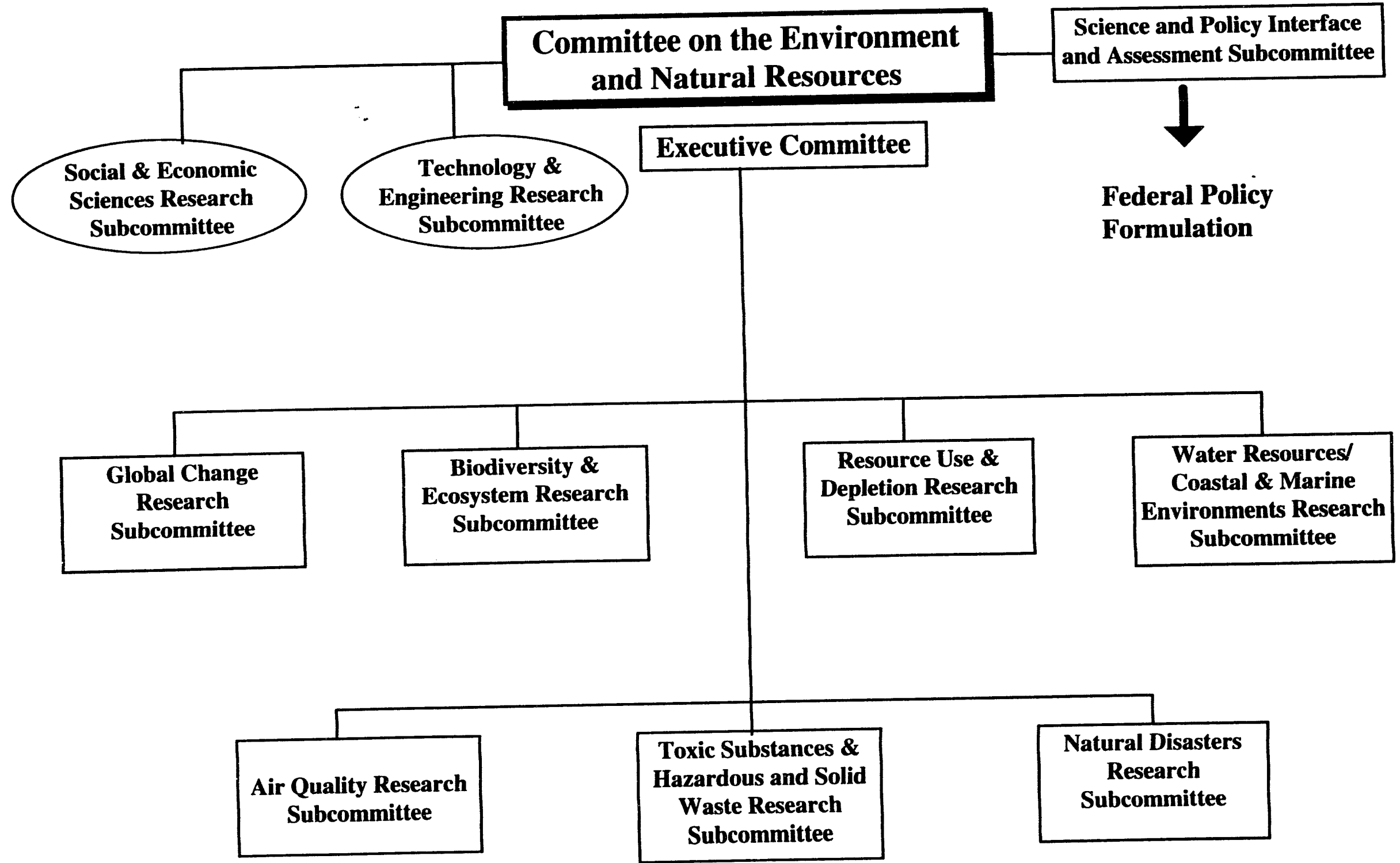




\section{National Science \& Technology Council}

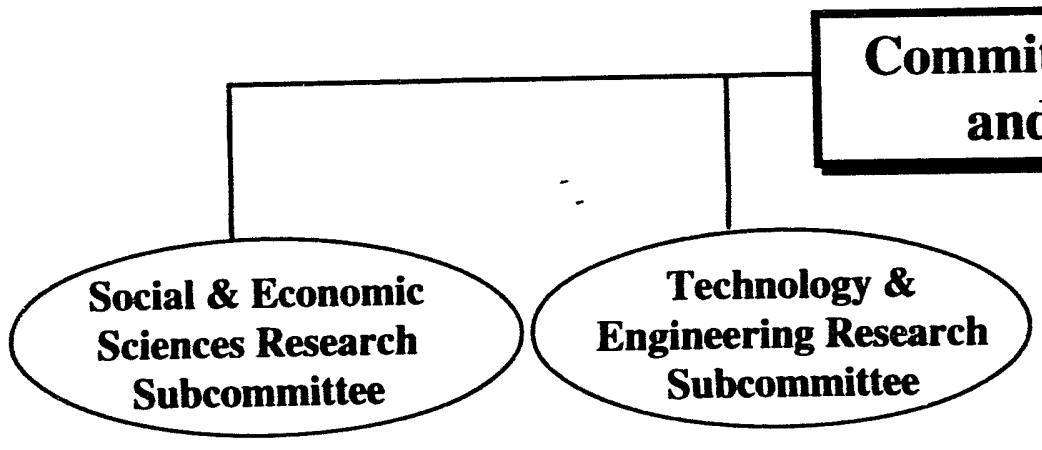

mittee on the Environment and Natural Resources

\section{Executive Committee}

Recommend overall environment and natural resources R\&D budget, develop recommendations for dealing with managent and budget issues that span more than one mance subcommittee or more than one FCCSET committee, e.g-, major facilities such as ships and aircraft, design the $U$. component of an integrated international ground- and space-based system for long-term systematic observations, including the data management system, of the environment and natural resources, provide liaison with the Private Enterprise/Government Interaction

Science and Policy Interface and Assessment Subcommittee

Co-chaired by OSTP, CEA and OEP. Charged with maintaining an effective science-policy interface, through close interaction with both technical and policy offices within the White House and the agencies.

Committee.

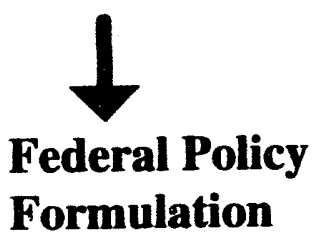

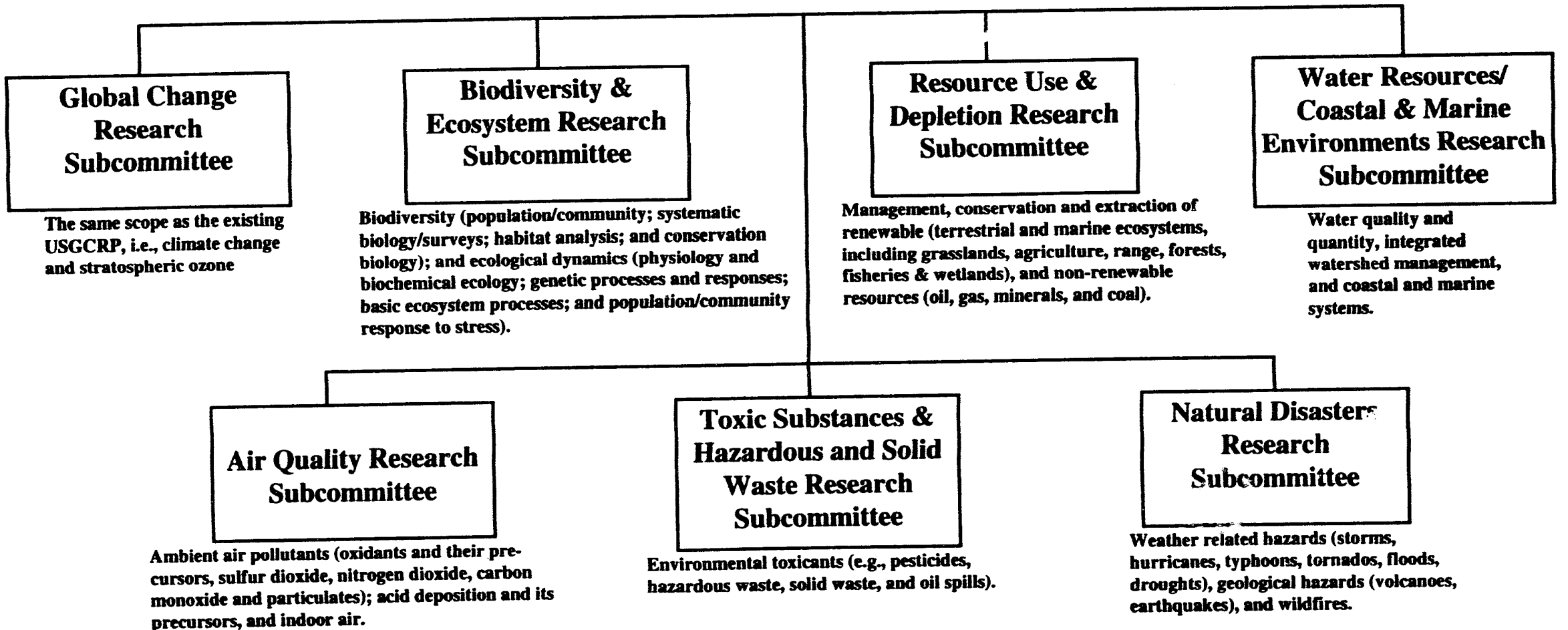


Information and Communication R\&D

Environment and Natural Resources Research

Civilian Industrial Technology R\&D

Education and Training R\&D

Transportation R\&D

National Security R\&D

International Science, Engineering, and Technology R\&D

One of the Council's first tasks is a comprehensive review of federal spending on R\&D, a process which is well underway within the Committee on Environment and Natural Resources (CENR). Indeed, CENR expects this process to be completed by September 1st. In theory, the various agencies involved in climate cha ige research, for example, will rank their numerous climate change programs for the NSTC, which will then evaluate the programs based upon the extent to which they are consistent with national environmental policy. This process is intended to enable the Council to exert a profound influence on funding and research priorities.

Of all of the Council's nine Committees, CENR has probably gone the furthest in establishing mechanisms to link science more closely to policy-making. For example, each of CENR's subcommittees (on Global Change, Biodiversity and Ecosystem Research, Resource Use and Depletion, Water Resources/Coastal and Marine Environments, Air Quality, Toxic Substances and Hazardous and Solid Waste, and Natural Disasters) has research components dealing with assessments, mitigation, impacts and adaptation, and socio-economic driving forces; and each of these subcommittees will have a Vice-Chairman from the policy community. Moreover, CENR has established a subcommittee to deal exclusively with social and economic science, and a high-level Science and Policy Interface and Assessment Subcommittee. The latter, run jointly by the Office of Science and Technology Policy (OSTP), the President's Council of Economic Advisors (CEA) and the White House Office of Environmental Policy (OEP), will have as its primary mission coordinating CENR's contribution to the formulation of federal environmental and natural resources policy.

CENR is further along than the NSTC's other eight committees in developing the science and policy interface in part because of the personal influence of its key organizers, but also because it has had relatively more time than the other committees to evolve in this direction. Indeed, the assessments function was added to the CEES (CENR's predecessor) portfolio about two years ago, principally as a result of some discussions between Robert Corell - the Chair of the CEES-and Alan Bromley, at the time the President's Science Advisor, both of whom concluded that adding assessments was a natural and "logical direction for a mature program to take." As a consequence of this head start in adding assessments and because the Administration considers climate change among its top environmental priorities, CENR is unlikely to be seriously affected by the NSTC's national review of R\&D priorities. In any case, the coordinators of the global change research program are quick to point out that their program has, all along, conducted its own rigorous internal and external review of priorities.

\section{THE CLINTON ADMINISTRATION AND CLIMATE CHANGE ASSESSMENTS}

The Clinton Administration's emphasis on linking science more closely to policy-making has already directly influenced the U.S. climate change program. The establishment of a policy-maker (Sue Tierney, the Department of Energy--DOE--Assistant Secretary for Policy, Planning and Program Evaluation) as a Vice-Chair of the Global Change Research Subcommittee, for example, is a unique contribution of this Administration, as is the form the current assessments function is taking; under the Bush Administration, "assessments" would not have been so broadly interpreted.

None of the focus on the science and policy nexus should be particularly surprising given the histories of some of the key Clinton advisors. Al Gore, of course, has been a long-standing supporter of policy action to address global warming, which he has described as "the most serious threat we have ever faced." Moreover, the President's Science Advisor, John H. Gibbons, was previously the Director of the Office of Technology Assessment (OTA) of the U.S. Congress, in which capacity he was regularly asked by Congressmen for scientific input to the climate change policy decisions they 
confronted. For example, Gibbons presided over the recent OTA study of "Systems at Risk from Climate Change"-an early attempt to link science more directly to policy-making. The study was designed to help identify "how decisions that Congress and the Federal agencies might make in the next 5 to 10 years" might affect our ability to deal with climate change over the next 25 to 100 years."

In this respect, the Clinton Administration differs fundamentally from its predecessor. As State Department Counselor Tim Wirth recently put it,

The essential difference between the Clinton Administration and the previous

Administration on climate is that we take the science of this issue very seriously and, as a consequence, are developing a national climate change policy to use in playing a leadership role in promoting an effective global response."

The Administration moved quickly to implement its agenda. For example, soon after entering office, key cabinet officials began reviewing U.S. environmental policy. Subsequently, the President issued a Presidential Review Directive, PRD-12, which established an inter-agency task force at the Assistant Secretary level to conduct a thorough and coordinated evaluation of the government's environmental work. ${ }^{12}$ PRD-12's Working Groups examined about a dozen different subjects, including biodiversity, oceans, trade and environment, and climate change. They issued their recommendations to the President on 15 February 1993. Shortly thereafter, the Climate Change Working Group's recommendations were endorsed in a Presidential Decision Directive (PDD) ${ }^{13}$ on climate change policy. It was these recommendations that were, in large part, reflected in President Clinton's 1993 Earth Day Speech. The national strategy elucidated by the President included a Climate Change Action Plan for limiting greenhouse gas emissions to 1990 levels by the year 2000 , as well as the establishment of two working groups, one to examine how to continue greenhouse gas reductions beyond 2000 , and another, nicknamed "Car Talk," to examine options for improving vehicle fuel economy and constraining the growth in vehicle use.

PRD-12's Working Group on Climate Change made other recommendations which, because they reflected an inter-agency consensus, did not need to be sanctioned directly by the President in his PDD. For example, one of the Climate Change Working Group's recommendations was that a senior level, interagency committee of policy and research managers should be set-up to determine the specific questions policy makers need answered with regard to climate change and the specific areas in which new research and assessment programs should be implemented, existing ones strengthened, and less relevant ones dropped. The President's Science Advisor, John Gibbons, requested on 8 July that the CEES Subcommittee on Global Change Research provide suggestions for implementing this recommendation and, in preparation for the FY96 budget, he also asked the Subcommittee to be prepared to evaluate how well the climate change program is meeting the needs of policy makers, and subsequently to develop a plan for re-ordering, if necessary, the priorities of the newly broadened assessments program. ${ }^{14}$

A few months later, Dr. Robert Watson, OSTP's Associate Director of Environment, outlined the new features of the assessment program in testimony before the Congress. ${ }^{15}$ According to Watson,

The Administration recognizes that the scope of the existing USGCRP is too narrow to provide effective comprehensive assessments of global change. Thus the Administration is committed to expanding the scope of the Program to meet the needs of decision makers...it is now recognized that the program must be strengthened in certain areas, such as research on: (a) the socioeconomic aspects of environmental changes; (b) the impacts of, and adaptation to, environmental changes; (c) the mitigation of environmental changes, and (d) the development of policy-relevant tools such as end-to-end integrated models.

The Administration's FY 95 request for assessments-policy sciences research and integrated assessments modeling-almost doubled agency-wide from about $\$ 18$ million to about $\$ 34$ million. The Department of Energy (DOE) accounted for about $\$ 5.8$ million of this amount (up from $\$ 3.9$ million last year), and the Environmental Protection Agency for about $\$ 4.0$ million (up from $\$ 1.9$ million last year). 
$\$ 18$ million of the total was requested for the NSF (\$8 million for Integrated Assessments and \$10 million for policy sciences research), up from about $\$ 2-3$ million the year before.

Within the DOE, it was the Policy Office that passed on to the DOE Office of Energy Research (OER), which coordinates the Agency's climate change research, internal guidance consistent with OSTP's directive to expand the assessments function. The internal guidance was to initiate a program of research and assessments on ecosystem and other impacts at a level necessary to "participate in credible estimates of potential impacts and the potential for adaptive policies to mitigate impacts... ." About $\$ 3.5$ million of the total FY95 DOE Assessments funds of $\$ 5.8$ million was to be spent on integrated assessments (IA) tools within OER's Environmental Sciences Division (ESD)-up from $\$ 1.7$ million in FY94 - with the balance of the amount to be spent by the DOE Policy Office.

In August of 1993, OER's Environmental Sciences Division (ESD) invited the climate change program managers at each of the DOE Labs to attend a meeting in Washington designed to help ESD flesh-out the details of an expanded IA program. Although ESD had been funding IA work for some time, the August meeting was the first major opportunity for the DOE Laboratory climate change program managers to discuss the future direction the IA program should take. There was considerable confusion and disagreement at the meeting, with the Lab representatives arguing that IA should involve a "toolbox" of techniques, each suited to the particular assessment question to be addressed, rather than the development of large, complex, IA models comprised of smaller, coupled economic, ecological, atmospheric and other models. To help establish a consensus on how best to proceed with the DOE's IA program, ESD and the Lab representatives agreed to organize a series of workshops on IA to be held later this year.

\section{A CRITIQUE OF THE NSTC AND THE CLIMATE CHANGE ASSESSMENTS PROGRAM}

The national reorganization of science and technology R\&D is clearly a step in the right direction. The establishment of the NSTC raises the profile of national science and technology policy by elevating decision-making to the Cabinet level of government. In theory, the NSTC also streamlines government by consolidating the work of the Federal Coordinating Council for Science Engineering, and Technology, the National Space Council, and the National Critical Materials Council. Moreover, whereas the previous inter-agency processes addressed only a handful of cross-cutting initiatives, such as high performance computing and climate change, the NSTC is designed to address science and technology policy in every sector across the Federal government.

Although it is too soon to judge how effective the NSTC will be, there are some grounds for concern. First, the national reorganization of S\&T policy has, thus far, only been codified in an Executive Order, ${ }^{16}$ rather than through Congressional legislation. The danger, as one Congressman recently put it, is that a "science council created with the stroke of one president's pen can just as easily be abolished by the next occupant of the White House." ${ }^{17}$ Given the potential significance of the re-organization, it would be advisable to seek a Congressional mandate for the NSTC as soon as possible.

One of the key criticisms of the previous FCCSET process was that it lacked the teeth to set priorities by virtue of the fact that it had no budgetary authority. It is not at all clear that the NSTC will be any more effective. According to Gibbons, the NSTC will operate "in parallel" with the preliminary budget discussions each federal agency has with the OMB. Neither the NSTC nor the OSTP will have the authority to veto various budget decisions. While it is true that the Council-unlike its predecessor-is comprised of cabinet-level officials who have significant influence over the budget, in practice, these are very busy people; it is not at all clear that they will devote adequate time to the Council or to enforcing its agenda.

An additional concern is the possibility that rather than streamlining government, the creation of the NSTC will actually result in the growth of a large and costly bureaucracy. The NSTC has nine Committees and each Committee has a myriad of Subcommittees. The CENR, for example, is comprised of a Full Committee, a Science and Policy Assessment Group, a Risk Assessment Group, seven Issue Subcommittees (viz. the Toxic Substances \& Hazardous and Solid Waste Research Subcommittee, and the Natural Disasters Research Subcommittee), and two Disciplinary 
Subcommittees, one on Social and Economic Sciences and the other on Technology and Engineering. Moreover, within each of the Subcommittees, there will be numerous Working Groups dealing with systems structure and function, socioeconomic driving forces, impacts/adaptation, mitigation, assessment, and education and training. Unless carefully attention is paid to restricting the NSTC's growth, it could very quickly exceed in size the various organizations it was meant to replace.

Part of the motivation behind the creation of the NSTC was the Administration's desire to link S\&T more closely to policy-making. A similar desire motivated the Administration to expand the assessments function within the global change research program. Although in percentage terms the assessments budget is among the fastest growing components of the climate change program-almost doubling between FY94 and FY95-in absolute terms it is still only a microscopic part- $\$ 34$ millionof the proposed FY95 climate change budget of $\$ 1.8$ billion. Within the DOE, for example, the increase in funding amounts to enough to finance the work of only about 8-10 additional DOE Lab scientists. Many more scientists in academia will be funded thanks to the jump in NSF's assessments budget and to the lower overhead costs at universities, nevertheless $\$ 34$ million is only a drop in the climate change bucket. One has to question national priorities when the climate change program's entire assessment budget is only funded at a level comparable to the budget of a single, pork-barrel-driven project like the DOE's National Institute for Global Environmental Change (NIGEC). ${ }^{18}$

To be fair, a legitimate concern is the extent to which the assessments community is presently able to absorb a huge increase in funding. There are numerous examples in science of program managers who, in their haste to rationalize the huge increases in funding they've received, end up financing projects of dubious scientific value. It is not unreasonable to scale-up slowly a program as a means of assuring that the quality of the work does not suffer. However, if this is part of the reason for the small size of the assessments program, one can only wonder why the scaling-up did not begin at the very inception of the GCRP, instead of years later. Part of the answer relates to the political atmosphere at the time. As indicated above, the Clinton Administration, unlike its predecessors, is committed to taking action to address climate change. It was previously politically less acceptable to emphasize climate change assessments. But a more important explanation is the natural tension that exists between scientific research on the one hand, and the assessments function on the other. Ideally, there should be constant communication between researchers in the two areas. As assessment researchers identify key uncertainties that have a disproportionately large human impact and, hence, a large impact on policy decisions, that information should be used to help focus the scientific research agenda. Instead, the two communities have tended to interact very little.

This is really nothing new, as the National Acid Precipitation Assessment Program (NAPAP) suggested years ago. NAPAP, which was set-up to study the vexing problem of Acid Rain, was an early and on the whole impressive attempt to use an inter-agency process to address a large and complex problem at the intersection of science, technology, and policy. As with the global climate change program, to which it is often compared, ${ }^{19}$ its goals were, among other things, to improve the scientific and technical understanding of the underlying processes as a means of furthering effective policymaking to address the problem. NAPAP was not, however, entirely successful. Its Oversight Review Board $^{20}$ listed nine main lessons to be learned from the experience, one of which illuminates the tension between science and assessments. The Board concluded that NAPAP's budgets and timelines should have been determined by assessment needs, yet instead,

the preponderance of NAPAP's money and its available time were extended on science, leaving assessments inadequately supported...somewhere along the way the assessments focus articulated earlier was lost and priorities appeared to be set by scientific and technical rather than assessment needs...the program [may have fallen] capture to the scientific thrust to use its massive resources to make progress on otherwise underfunded matters of great inherent interest to the scientific community. ${ }^{21}$

There are obviously some important differences between NAPAP and the climate change program, none the least of which is that the scientific parameters of the former were much better defined than are those of the latter. Nevertheless, the general thrust of this NAPAP lesson remains relevant today: the 
assessments function should be linked more closely to the science of the program and should play a greater role in focusing the scientific research agenda.

One additional lesson identified by the NAPAP Oversight Review Board should be especially noted by those connected to the climate change program's assessment component. The Board pointed out that,

Politics is the art of making acceptable decisions. Applied science and assessment aspects of a policy problem may be large, but they are nested in the political process of making decisions. Unless such science and assessment is seen to contribute to making those decisions, it will wither or be ignored. ${ }^{22}$

This lesson suggests that as the budget for climate change assessments increases, particular attention needs to be paid to expanding the mechanisms for participating in the national and international policymaking process. Integrated Assessments (IA)-primarily the development and testing of quantitative tools (principally models) for conducting "end-to-end" assessments-is currently among the largest climate change assessment programs funded, yet it may take years before this necessary and valuable activity begins yielding results that can be used reliably in the formulation of policy. Because the fate of the climate change research program will ultimately rest with the Congress, particular attention needs to be paid to mechanisms for communicating scientific results to Capitol Hill. Relying primarily on infrequent "expert" testimony before Congressional committees is both primitive and inadequate. For one thing, legislators, in order to appear as "balanced" as possible, tend to arrange testimony on "both sides" of a given issue, hence this process often creates the misleading impression that the scientific community is evenly divided on the question of climate change.

In conclusion, although the establishment of the NSTC represents an important opportunity to integrate climate change assessments more effectively with national policy-making, particularly given the heavy emphasis placed within the CENR on the science/policy interface, it remains to be seen if this new structure for determining national science and technology priorities will be implemented effectively. In any case, the future viability of the climate change assessment program will hinge on the extent to which its work influences national and international policy decisions. This is particularly true in an era in which the country is holding scientific research accountable as perhaps never before.

\section{REFERENCES}

1. Letter to Dr. John H. Gibbons from Senator Quentin N. Burdick, Chairman, Committee on Environment and Public Works, October 4, 1991; and Letter to Dr. John H. Gibbons, from Ernest F. Hollings, Chairman, Committee on Commerce, Science, and Transportation, October 8, 1991.

2. The Oversight Review Board of the National Acid Precipitation Program, "The Experience and Legacy of NAPAP," Report to the Joint Chairs Council of the Interagency Task Force on Acidic Deposition, (April 1991)

3. See the section entitled "The Future of the NSF," in Senate Appropriations Committee Report on HR2491 to fund the Departments of Veterans Affairs and Housing and Urban Development, and independent agencies. 103-137. See also, "Could America Afford the Transistor Today?," Business Week, March 7, 1994, p 80-84.

4. Ibid.

5. Environment Week, August 12, 1993 (King Communications Group, Inc.).

6. The two men outlined their concerns in a 17 August memo to the heads of each Cabinet department and agency. See, for example, "Clinton moves to Manage Science," Science, Vol. 26, (24 September 1993), p 1668.

7. The White House, Office of Media Affairs, "Statement of the President," (November 23, 1993).

8. Discussions with Robert Corell, Chairman Subcommittee on Global Change Research, March 11, 1994.

9. Senator Al Gore, Earth in the Balance, (New York: Houghton Mifflin Company, 1992), p 40.

10. Letter to Dr. John H. Gibbons, Director, Office of Technology Assessment, from Sens. Quentin N. Burdick, John H. Chafee, and Max Baucus, Committee on Environment and Public Works, October 4, 1991. 
11. Timothy E. Wirth, "Developments in U.S. Policy Toward Global Climate Change, U.S. Department of State Dispatch, May 31, 1993 (Vol. 4, No. 22), p 400. Of course, as Michael Schlesinger and others have pointed out, the hallmark of the Clinton Climate Change Action Plan is only dubiously connected to good science: regardless of the near-term policy goal and regardless of the climate target (high or low), the optimal global emission rate as a function of time is clearly not the Administration's proposal to reduce greenhouse gases by the year 2000 to the 1990 emission rate.

12. U.S. Policy Toward Global Environment Affairs (PRD-12)," U.S. National Security Council, February 15, 1993.

13. PDDs are internal statements of policy within the administration. They express to the various agencies of government the President's wishes and demands for action.

14. Memorandum for Frederick M. Bernthal, Acting Director, National Science Foundation, From John H. Gibbons, Assistant to the President for Science and Technology, Subject: PRD-12 Response, July 8, 1993.

15. "Statement of Dr. Robert T. Watson, Associate Director for Environment, Office of Science and Technology Policy," Before the Committee on Science, Space, and Technology, U.S. House of Representatives, November 16, 1993.

16. Executive Order 12881 of November 23, 1993, "Establishment of the National Science and Technology Council."

17. Rep. Rick Boucher, "Getting Serious About Science-Policy Reform," Issues in Science and Technology (Winter 1993-1994), p 27.

18. NIGEC's budget in FY94 was $\$ 11.5$ million. That same year the agency-wide budget for climate change assessments was about $\$ 18$ million. Although a small portion of this amount is devoted to "assessments," the vast majority is spent on climate change science.

19. Richard Monastersky, "The \$1.5 Billion Question, Can the U.S. Global Change Research Program Deliver On Its Promises?," Science News, Vol. 144 (September 4, 1993), p 158.

20. NAPAP, Op. Cit.

21. Ibid., pp 26-27

22. Ibid., p 22. 

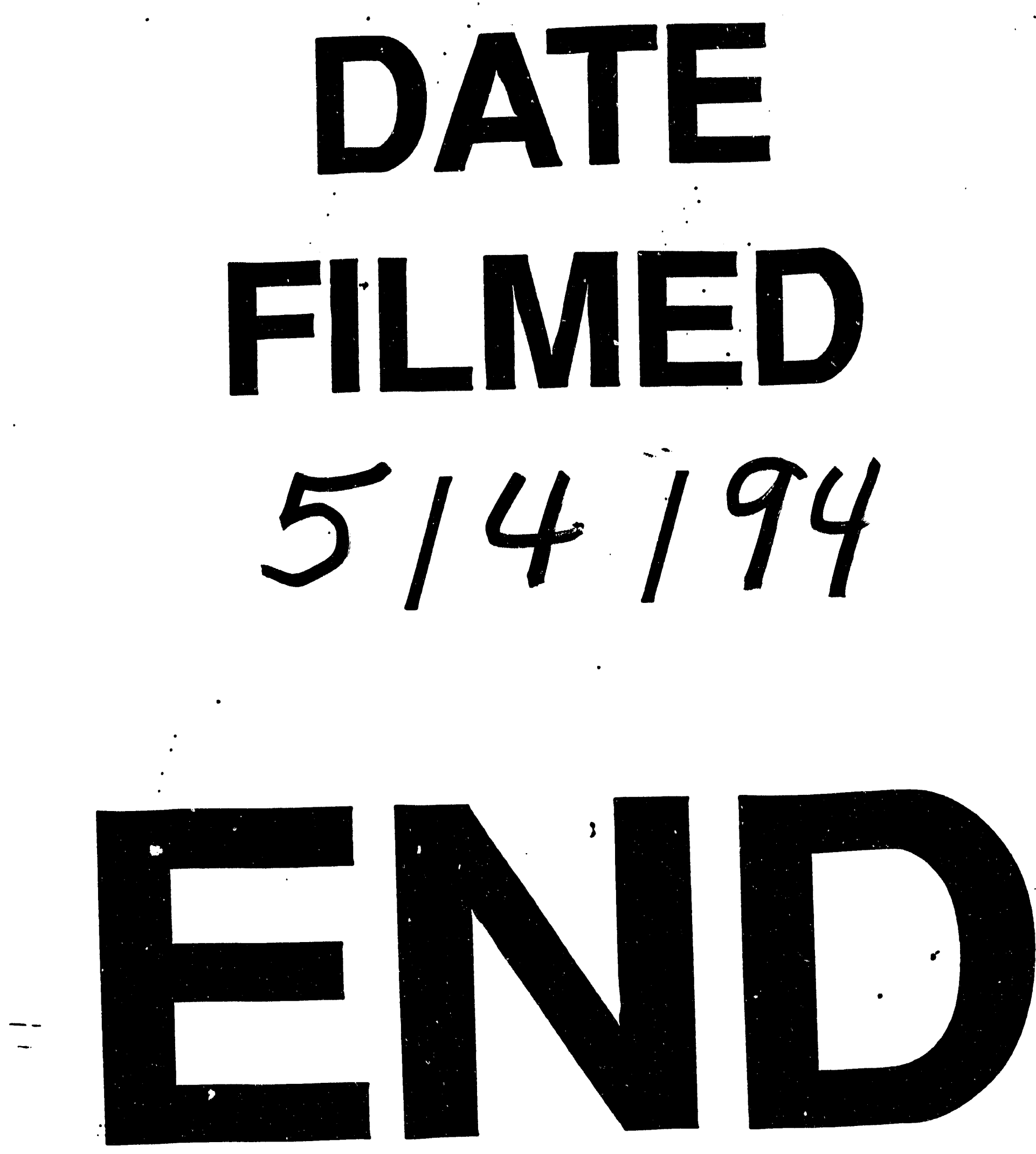
ran 